Dept. of Hygiene,

Faculty of Vet. Med., Assiut University,

Head of the Dept. Prof. Dr. Nabila Gazia.

\title{
THE VALUE OF SOYBEAN MEAL AS THE ONLY PROTEIN CONCENENTRATE IN \\ BROILER FEEDING \\ (With 3 Table)
}

By

\section{NABILA GAZIA; H.M. ABDEL-HAFEEZ and H.K. SHOEIB}

(Received at 20/2/1993)

\section{استخداه كسب فول المويا كمدكل بدوتينت وحيد في حغذية كناكيت التسميد}

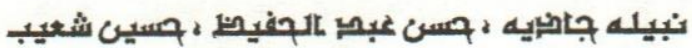

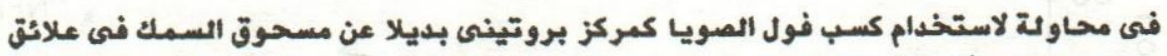

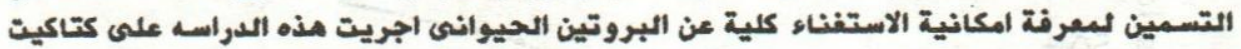

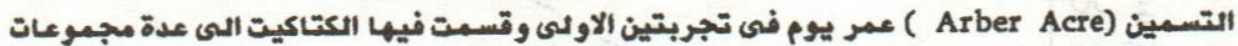

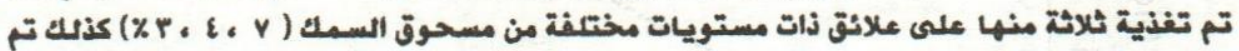

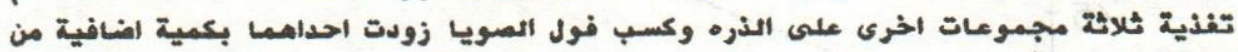

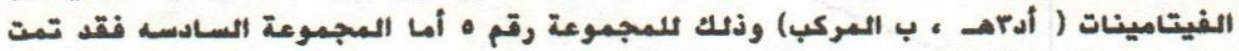

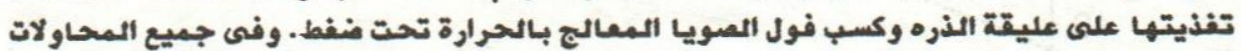

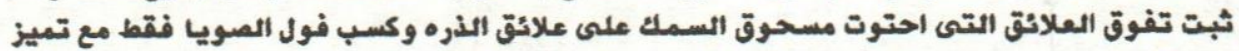

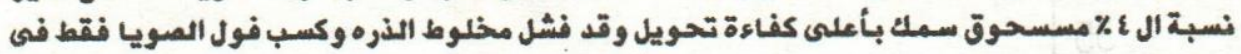

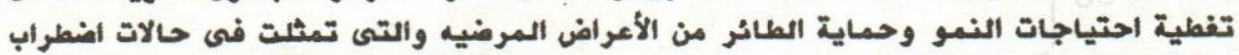

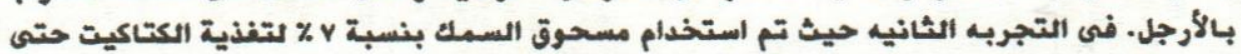

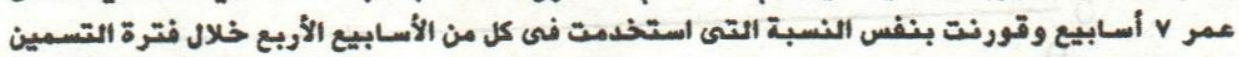

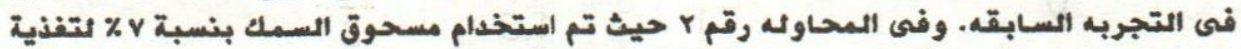

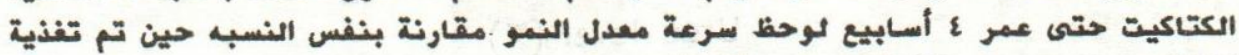

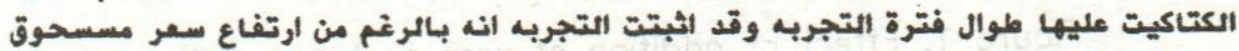

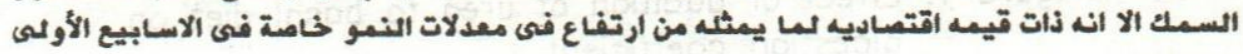


SOYBEAN MEAL \& BROILER FEEDING

\section{SUMMARY}

Two trials were conducted to study the extent to which the broilers are in need for animal protein. The effect of all plant protein diet (C/SBM) and meai (FM) supplemented-ones was tested in relation to the bird performannce. One day-old Arbor Acre broiler chicks were used in trial 1 to trace the effect of 10 treatments for 7 weeks feeding period. 7,4 \& $2 \%$ FM diets, C/SBM with extra vitamins ( $A D 3 E$ \& B complex) and corn/autoclaved SBM diets (C/SBM "A" ) were conducted in a trial and the level of $7 \%$ FM was tried to be fed for 1,2,3 \& 4 weeks of age and compared with the same level along the whole fattening period in another trial. All FM diets were surpassing the C/SBM diets in stimulating the growth together with increasing the efficieency of feed conversion and the $4 \%$ level was the optimal one. The C/SBM diets failed to satisfy the needs for growth and to protect the chicks against nutritional disorders, where leg disorder was appeared in the chicks. However, rapid growth was achieved if the supplementation with the FM was confined to the first 3 or 4 weeks of age. FM diets in spite of being costy, it is proved to be more economic.

\section{INTRODUCTION}

Since several decades, poultry rations relied almost totally on meat scraps and fish meal for protein. It became increasingly evident, that animal products, especially fish products, provided some factor (s) in addition to the known B vitamins and methionine which in turn improved the nutritive value for chicks fed a corn-soybean meal diet.

30-50 years ago, there was a great deal of prejudice against plant proteins of all kinds for animal and poultry diets. Early research findings, contributed to the development of high-efficiency poultry rations containing soybean meal as the only source of supplementary protein, have been reviewed by HAYWARD (1959).

In many countries, it was obliged (by law) for poultry diet compounders to add a considerable amount of $\mathrm{fish}$ meal (as in Germany). However, later on this requirment was steadily decreased, and in diets based on soybean meal, fish meal can be dispensed with.

Assiut Vet. Med. J. Vol. 29, No. 57, April 1993. 
NABILA GAZIA et al.

It was a great surprise that the results were too variable and adverse. Thus in a vast number of experiments, (WALDROOUP et 1., 1967; WEGNER, 1970; GRIFFITH \& SCHEXNAILDER, 1971; HERSTAD, 1973: AVILA \& BALLOUN, 1974 and BJORNSTAD et al., 1974), the inclusion of fish meal, in moderate levels, in diets for chicks have created an improved performance which cannot be explained by its content of known nutrients, although others (FULLER, 1967 and VOGT \& STUTE, 1967) could not be able to demonstrate a similar effect consistly.

This study aimed to solve this problem, at least in Egypt as the local production of $f$ ish meal is not able to cover the need and trying to compensate for in diets mainly based on soybean meal. The effect of all plant protein-diet or fish meal-supplemented ones was tested in relation to the bird performance, in different stages, expressed in growth and feed conversion index and cost.

\section{MATERIAL and METHODS}

Birds:

215 of the one day-old commercial Arbor Acre broiler chicks were used to trace the effect of 11 treatments in two separate trials for a period extended for 7 weeks of age in each. The chicks were randomly distributed into eleven groups each of 20 chicks of which 6 groups were experimented on in the first trial and other 5 in the second trial of which the control group is only 15 in number.

\section{Diets:}

In the first trial three different levels of FM $(7,4$ and $2 \%$ ) were tested in groups 1,2 \& 3 compared with a C/SBM diet in group 4. In groups $5 \& 6$ the plant protein diet was tried to be compensated for by the addition of extra vits. ( $A D_{3} E$ \& $B$ complex) in group 5 and improving the quality of SBM by autoclaving in group 6 .

In the second trial the rations fed to the chicks till the age of 7 weeks were supplemented by $7 \%$ FM in group 1 and compared with the same level fed for $1,2,3$ \& 4 weeks of age in the other four groups respectively.

The feeding stuffs corn, SBM \& FM in addition to bran, bone meal and limestone were used in formulating the experimental diets after being analyzed for its chemical composition (table 1).

The total amount of feed consumed by each group was weekly recorded where it is divided by the mumber of birds of to 
SOYBEAN MEAL \& BROILER FEEDING

extract the average consumption per bird. The chicks were individually weighed every week in order to follow the body weight development.

The different data were statistically analyzed following the methods cited by SNEDECOR (1956).

\section{RESULTS}

As some disease conditions were anticipated in the whole plant groups, the chicks were daily examined for the development of any unthrifty symptoms. It was noted in the first trial that nonspecific leg disorder conditions appeared on all of the C/SBM diet chicks early in age during the first 10 days. On the contrary a level of FM as low as $2 \%$ succeeded in protecting against this disorder. The supplementation of the all-plant diet with extravitamins saved $75 \%$ of the chicks while autoclaving the soya meal saved only $20 \%$ from the C/SBM-birds.

In the second trial, the results indicated that feeding a diet supplemented with $7 \%$ FM is needed to protect the chicks from the harmful effect of the whole plant diets and the supplementation should continue for the first two weeks of age from the health - point of view. While, not less than 3 weks are needed if the other performance criteria are considered. Supplementing the diet for only the first week protects $75 \%$ of the chicks while while the rest showed the same disease condition noted in trial 1.

Decreasomg the rate pf FM addition from $7 \%$ to $4 \%$ did not affect the level of feed consumption as it averages in both $3983 \mathrm{~g}$ while decreasing the FM level to $2 \%$ decreased the consumption by about $1 \%$. The removal of FM supplementation clearly reduced the feed intake by $14.06 \%$ and it appeared that the extra vitamins or SBM autoclaving were of no effect in this respect.

Regarding the live weight, there were no significant differences between the groups 1 \& 2 (fed the $7 \& 4 \%$ FM) in trial 1, while in group $3(2 \% \mathrm{FM})$ lesser weight was attained. The growth in the C/SBM group (4) was found to be clearly affected by the absence of the FM factor and the addition of vitamins in group 5 did not improve the growth with the exclusion of the unexpected rise in the $7^{\text {th }}$ week. Autocloving the SBM in group 6 made no difference in the end weight when compared with that of group 4 in spite of the unexplainable increase in rate in the second week.

In trial " 2 " also supplementing the diets with $7 \%$ for the first week or two of age was found to be insufficient for the 
NABILA GAZIA et al.

growth to be optimal while addition of the animal protein for the first 3 or 4 weeks covered the need for the animal protein factor and the groups $4 \& 5$ showed an end weight statistically different from that of the first group. FM diets seemed to be more palatable for the chicks than the C/SBM diets as feed consumption was noted to decrease as the chicks were turned form the FM diet to the plant one.

The feed conversion index "FCI" in trial "1" was nearly equal in groups $1 \& 2$. while in group 3 , each bird consumed 300 $\mathrm{g}$ more diet to gain $1 \mathrm{Kg}$. The chicks fed the diets free of FM also consumed more feed than group 1 for every $1 \mathrm{Kg}$ gain (700, $175 \& 638 \mathrm{~g}$ ) for groups 4,5 \& 6 respectively.

In the second trial the FCI in groups 4 \& 5 compared well with that of group $1(2.54,2.56 \& 2.52$ respectively), while in groups 2 \& 3 where the FM addition period was shortened to one or two weeks, the conversion rate was lowered.

\section{DISCUSSION}

Trial (1): The results revealed that the fish meal diets were surpassing the corn-soybean meal diets and promoting the growth of broiler chicks, these observations agreed with that of HERSTAD, 1973; BJORNSTAD et al., 1974; YAMANE et al., 1982 and REDDLY \& ESHWARIAH, 1989, however, it could be safely concluded that 4\% FM throughout the 7 weeks period supported rapid growth in broilers, the same level was early reported by CHRISTIANSEN et al., 1940 and WHITSON et al., 1945 and can be advised that in case of animal feed-shortage and high costing, a level of FM addition as low as $2 \%$ could be trusted with to supply the growth factors. This observed growth response confirms the earlier work of HEUSER and NORRIS (1944). Moreover, HERSTAD, 1978; YAMANE et al., 1982 and TRAVIN, 1989 reported that $2 \%$ FM level was adequate for satisfactory gains.

It is clear that the FM increased the efficiency of feed conversion and its absence increasing the feed intake $/ \mathrm{Kg}$ gain. This effect in addition to the increase in growth was recorded before by AVILA \& BALLOUN, 1974; HALGA et al., 1978; VAVAK et al., 1989; YAMANE et al., 1982 and RADDLY \& ESHWARIAH, 1989, while no differences were observed in other studies by WALDROUP et al., 1965; ROJAS et al., 1969 DAY \& DILWORTH, 1980 and HULAN et al. , 1988.

Trial (2): As concluded from this trial the FM should be included in the broiler diets during the first three four weeks of age to guard against leg disorders, retarted growth or low feed conversion efficiency, this conclusion comes in line with that of VAVAK et al., (1980).

Assiut Vet. Med. J. Yol 29, No. 57, April 1993. 
Occurrence of the leg disorders in some chicks fed on C/SBM diets leads to the thinking in the improved nutritional balance provided by the FM to be the main factor protecting the ckicks against the disorders and similar result was reported by FULLER (1967), or on the other hand a certain factor in the SBM harmful for the bone metabolism is neutralized completely by an antifactor in the FM, where this coincides with that recorded by SUNDE and BIRD (1951) PHEASANT and CARLSON et al. (1964) for turkey poults and confirmed to chicks by JENSEN and MRAZ (1966). As the appearance of these symptoms in a number of chicks but not all, lead to the belleve that this effect is subjected to genetical variations in the chicks, an explanation which recently proved by the continuous efforts of geneticists in producing C/SBM strain chicken by feeding a C/SBM ration for a breeding stock over more than 25 generations a fact cited by PATRICK and SCHAIBLE (1980).

The growth promoting effect of FM in addition to palatability, high feed conversion index collectively confirmed the necessity of FM supplementation in the first 3 weeks of age, the period of rapid growth rate and starter feeding. Increasing the length of FM addition has no beneficial effect on performance but on the contrary increasing the cost and negatively affecting the net income. It does not make any difference in cost or performance if the producer uses $7 \%$ or $4 \%$ FM in his broiler diets.

\section{REFERENCES}

Avila, E.G. and Balloun, S.L. (1974): Effect of anchovy fish meal in boriler diets. Poultry Sci., 53: 1372-1379.

Bjornstad, J.; Opstvedt, J. and Lune, G. (1974): Unidentified growth factors in fish meal; Experiments with organic arsenic compounds in broiler diets. British poultry sci., 15: $481-487$.

Carlson, C.W.; Saxena, H.C.; Jensen, L.S. and McGinnis, J. (1964): Rachitogenic activity of soybean fractions. J. Nutrition 82: 64-70.

Christiansen, J.B.; Deobald, H.J.; Haplin, J.G. and Hart, E.B. (1949a): Practical supplements for soybean oil meal in chick rations. Poultry Sci., 19: 18-22.

Day, E.J. and Dilworth, B.C. (1980): Comparison of menhaden fish meal and fish meal. Substitute in broiler diets. Poultry Sci., 59(1): 91-94.

Fuller, H.L. (1967): The value of animal protein supplements for broiler rations. Feed stuffs, 39: 20-35. 
NABILA GAZIA et al.

Griffith, M. and Schexnailder, R. (1971): Response of chicks to several sources of unidentified growth factors. Poultry Sci., 20: 1581-1586.

Halga, P.; Folea, O.; Stavila, S.; Halga, N. and Stan, V. (1978): Replacing fish meal in feeds for meat cnickens. Lucari stuntifice, Institutul Agronomic, Iasi, II; 81-82.

Hayward, J.W. (1959): Improved feed ingredient processing. Feedstuffs $31(34): 18-31$.

Herstad, 0. (1973): Herring meal and methionine supplementation in broiler feed. Meld. N.L.H. 52(16): 1-15.

Herstad, 0.(1978): Herring meal, meat and bone mea land pauzone in feed for chicks. Archiv fur Geflugelkunde 42(6): 221-224.

Hulan, H.W.; Ackman, R.G.; Ratnayocke, W.M.N. and Proudfoot, F.G. (1988): Omega-3 fatty acid levels and performance of broiler. Chickens fed red fish meal or red fish oil. Canadian Journal of Animal Sci., 68(2): 533-547.

Jensen, L.S. and Mraz, F.R. (1966): Rachitogenic activity of isolated soy protein for chicks J. Nut. 88: 249-258.

N.R.C. (1984): Nutrient requirement of poultry. $8^{\text {th }}$ Ed. National Academy of Scienses. Wash. D.C.

Reddly, V.R. and Eshwariah (1989): Effect of graded replacement of fish meal with vegetable proteins in broiler starter rations. Indian Journal of Animal Nutrition 6(2) 166-168.

Rojas, S.W. ; Lung, A.B. and deGuzman, R.V.N. (1969): Effect of peruvian anchovy Engraulis ringens meal supplemented with santoquin on growth and fish flavor of broilers. Poultry Sci., 48: 2045-2052.

Snedecor, G.W. (1956): Stattstical methods, $5^{\text {th }}$ ed. Iowa State Col1., Press. Amer. Iowa. U.S. A.

Sunde, H.L. and Bird, H.R. (1957): The niacin requirement of the young ringneck pheasant. Poultry Sci., 36: 34-41.

Travin, N.V. (1989): Changes in feed intake and growth of broiler chickens reared on diets containing varying amounts of animal protein. Referativnyl Zhurnal 3: 58-82.

Vavak, J.; Frydrych, Z. and Heger, J. (1980): Nutritive value of broiler diets without animal protein. Biologizace a chemizace Vyroby, Veterinaria 18(2): 117-126.

Vogt, H. and Stute, K. (1967): Versuche Uber den Volstandigen Ersatz von Fishchmehl durch Planzlice Eiweisstrager. 1. Mitteilung. Arch Geflugelked, 31: 299-314. 
SOYBEAN MEAL \& BROILER FEEDING

Waldroup, P.W.; Landes, D.R.; Kealy, R.D.; Greene, D.E. and Stephenson, E.L. (1967): Comparison of the growth stimulating properties of Vigofac and streptomycin in broiler diets with and without fish meal. Poultry Sci., 46: $974-976$.

Waldroup, P.W.; Walleghem, P.V.; Fry, J.L.; Chicco, C. and Harms, R.H. (1965): Fish meal studdies 1- Effect of levels and sources on broiler growth rate and feed efficiency. Poultry Sci., 44: 1012-1016.

Wegner, R.M. (1970): Kukenmastversuche mit und ohne Fischmehl mit und ohne salzausgleich in der ration. Arch. Geflugelkd 34: 135-139.

Whitson, D.; Hammond, J.C.; Titus, H.W. and Bird, H.R> (1945): The use of soybean meal in the diet of growing chicks.

II- Effect of different grains. Poultry Sci., 24: 408-416.

Yamane, T.; Nakazato, T., Nakajima, T. Ohmori, S. and Kosaka, S. (1982): The feeding Value of $f$ ish meal in broiler feed. Japanese Poultry Sci., 19(5): 276-285.

\footnotetext{
Table (1): chemical coupostition of the different

lagrediants used ( on dry wattar basio )
}

\begin{tabular}{|c|c|c|c|c|c|c|c|}
\hline Feed & $\begin{array}{c}\text { Dry } \\
\text { matter }\end{array}$ & $\begin{array}{l}\text { crude } \\
\text { protein }\end{array}$ & $\begin{array}{l}\text { ether } \\
\text { extract }\end{array}$ & Ash & $\begin{array}{l}\text { Crude } \\
\text { fiber }\end{array}$ & ca & Pav. \\
\hline Yellow çorn, sround & 90.20 & 9.72 & 3.45 & 1.85 & 1.85 & 0.03 & 0.15 \\
\hline Soybean oil mad'. & 92.50 & 50.20 & 1.70 & 6.30 & 4.30 & 0.32 & 0.36 \\
\hline Whear bran, coarse & 92.00 & 14.50 & 2.85 & 6.30 & 11.40 & 0.25 & 0.40 \\
\hline Fisn aval, 1 mported & 90.70 & 67.00 & 6.60 & 13.50 & 1.05 & 3.95 & 2.50 \\
\hline Bone wleal & 94.70 & 2.60 & 0.18 & 89.00 & 0.55 & 29.80 & 12.90 \\
\hline Llawestoule yround & - & - & - & 98.00 & - & 36.30 & - \\
\hline
\end{tabular}

Assiut Vet. Med. J. Vol. 29, No. 57, April 1993. 
SOYBEAN MEAL \& BROILER FEEDING

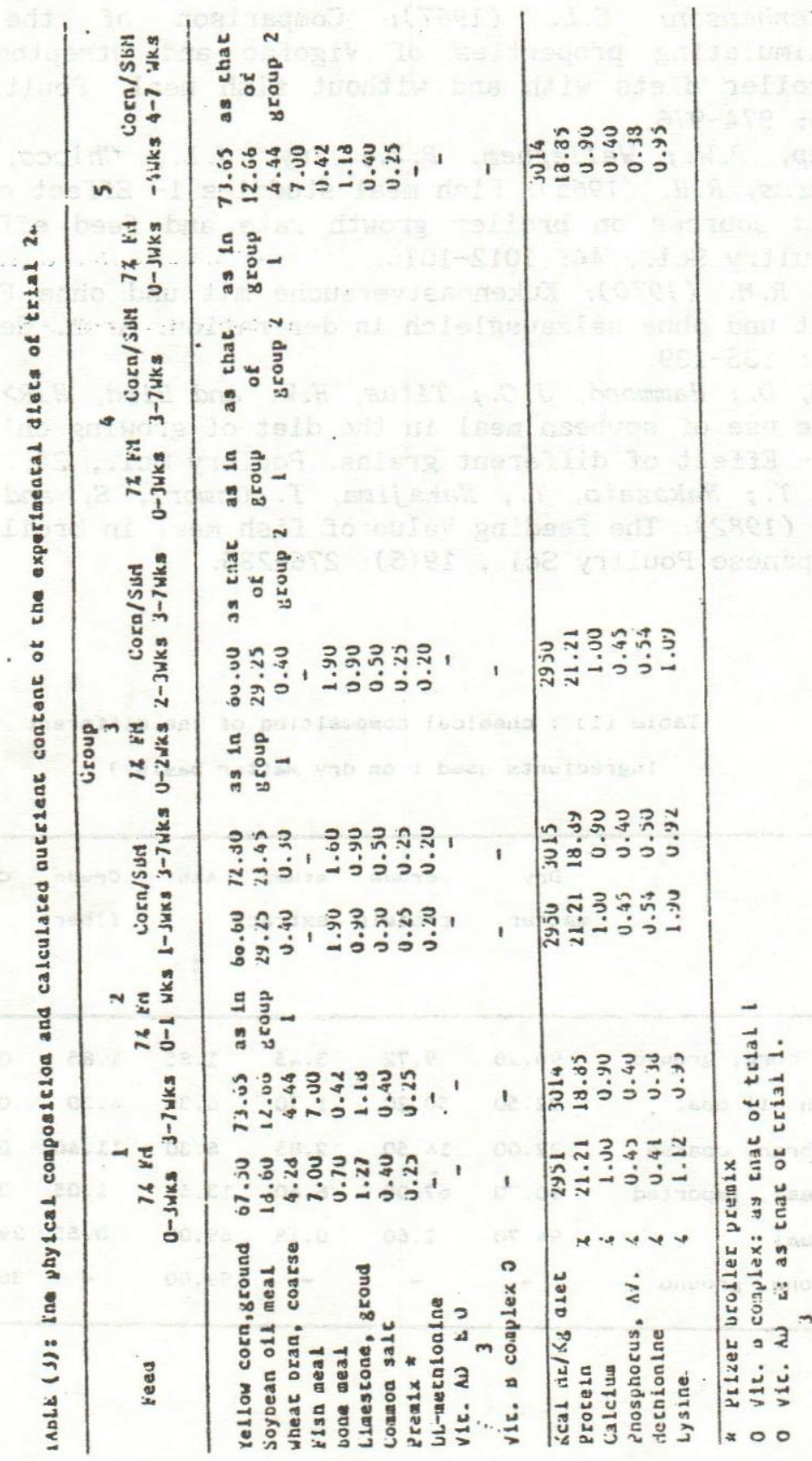


NABILA GAZIA et al.

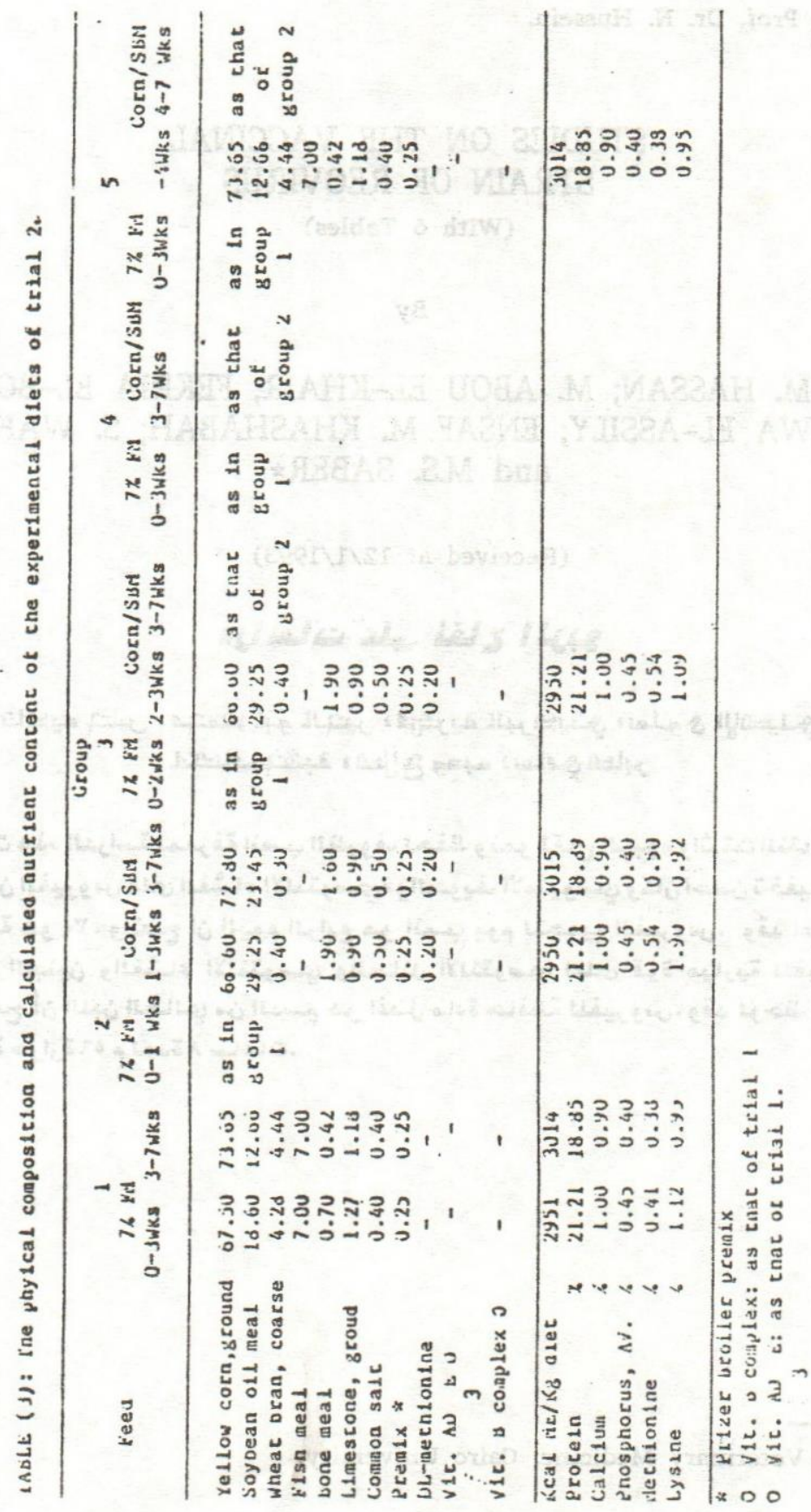

Assiut Vet. Med. J. Vol 29, No. 57, April 1993. 